\title{
In vitro Manipulation of Rumen Fermentation Efficiency by Fumaric acid - Bentonite Coupled Addition as an Alternative to Antibiotics
}

\author{
M. A. Abdl-Rahman \\ Department of Physiology, Faculty of Veterinary Medicine, Cairo University, Egypt \\ Faculty of Veterinary Medicine, Cairo University, Giza-12211, Egypt \\ Tel: 202-2864-5669 E-mail:mahmod.abdelhafez@gmail.com
}

\begin{abstract}
Short term in vitro incubations were used to evaluate the effect of fumaric acid - bentonite coupled addition on rumen fermentation effeciency. Ruminal contents from five steers were used for preparation of inoculums of mixed rumen microorganisms that were used in generatation of three treatment systems, negative control, fumaric acid treated, and fumaric acid - bentonite coupled treated. The fermentation pattern revealed that, this coupled addition was associated with an additional increase in propionic acid production and fermentation efficiency and was related to an additional decrease in methanogenesis and VFAs utilization index. Furthermore, it increased total VFAs concentrations and decreased $\mathrm{pH}$ value, ammonia nitrogen $\left(\mathrm{NH}_{3}-\mathrm{N}\right)$ concentrations and butyrate proportions. Meanwhile, it did not alter the proportions of long chain VFAs or cellulase activity. Conclusively, this coupled addition would improve the impact of fumaric acid on rumen fermentation pattern and can be appropriate alternative for antibiotic feed additives in improving ruminants feed efficiency.
\end{abstract}

Keywords: Bentonite addition, Coupled addition, Fermentation effeciency, Fumaric acid, Rumen fermentation

\section{Introduction}

During the last decades, considerable amounts of antibiotics were used in ruminant production for optimization of rumen fermenation pattern. However, increasing worries with antibiotic residues in meat and milk led consumers allover the world to oppose the usage of antibiotics in animal feeds. At the same time this risk fuelled the search for nonantibiotic alternatives, which might have similar effects on animal performance.

According to Diebold and Eidelsburger (2006), fumaric acid is one of the most hopeful in this regard because of its potential to reduce methanogenesis by sinking hydrogen during its conversion to propionate (Newbold \& Rode 2006). Increased hydrogen utilization by fumarate reducing bacteria could also stimulate cellulolytic bacteria and enhance cellulose digestion (Wallace et al. 2005). However, the inconsistent effects of fumaric acid on animal performance (Newbold \& Rode 2006), have limited its adoption. One of the major constraints to induction of fumaric acid effects, is that, the affinity of fumarate reducing bacteria to hydrogen is lower than the affinity of methanogens, as a result, the maximum potential of fumarate to divert $\mathrm{H}_{2}$ away from $\mathrm{CH}_{4}$ is limited presumably because methanogens utilize $\mathrm{H}_{2}$ more rapidly than fumarate-utilizing bacteria. Asanuma et al. (1999) suggested that fumarate-utilizing bacteria have a disadvantage in utilization of $\mathrm{H}_{2}$ compared with methanogens when the partial pressure of $\mathrm{H}_{2}$ is low. In this regard ciliate protozoa facilitate methanogenesis by consuming oxygen and establishing a high redox potential (Newbold et al. 1995). defaunating agents were found to strongly inhibit methanogenesis and direct hydrogen for propionates production (Santra et al. 1996).

Sodium bentonite is an expanded lattice clay of the montmorillonite group of minerals (Bates \& Jackson 1980) with high ion exchange capacity that binds a wide range of cations (Fenn \& Leng 1989). According to Wallace \& Newbold (1991), bentonite interferes with the efficiency of protozoal ciliary motion and thereby reduces the activity of ciliate protozoa. Because of the huge surface area of bentonite and the electrical charges on its surface, it slows the capture rate of microbes by protozoa allowing higher bacterial and fungal populations to remain within the ruminal fluid (Heijnen et al. 1991; Wallace \& Newbold 1991).

The present experiment was therefore conducted to investigate the effect of coupling bentonite to fumaric acid addition as a tool for potentiating fumaric acid effects on rumen fermentation pattern.

\section{Materials and methods}

This investigation was conducted in Department of Physiology, Faculty of Veterinary Medicine, Cairo University, Egypt. 


\subsection{Collection of rumen contents}

Ruminal contents used to prepare the treatment systems were collected from the rumen of five slaughtered steers. Collected ruminal fluids were strained through four layers of cheesecloth into a separating flasks previously gassed with oxygen-free $\mathrm{CO}_{2}$ and brought immediately to the laboratory. Srained rumen liqours were mixed with the buffer solution of Goering and Van Soest (1970) in the proportion 1:2 (v/v), flushed with oxygen-free $\mathrm{CO}_{2}$ and used as inoculums of mixed rumen microorganisms. Part of each buffered rumen fluid sample (blank) was not used as inoculum, immediately mixed with $0.3 \mathrm{~mL} \mathrm{H}_{2} \mathrm{SO}_{4} 10 \mathrm{~N}$ and used for determination of total VFAs concentrations before incubation.

\subsection{Preparation of treatment systems and in vitro fermentation}

Thirty milliliters of buffered rumen fluids were anaerobically transferred to $120-\mathrm{mL}$ bottles containing $200 \mathrm{mg}$ of feed sample (basal diet of steers, composition and chemical analysis is shown in table, 1) previously ground with a pestle and mortar to provide an even distribution of particle size. The following treatment systems were then prepared for each sample in duplicate tubes per treatment: negative control (no additives), fumaric acid treated $(0.5 \mathrm{mg} / \mathrm{mL})$, and fumaric acid - sodium bentonite coupled treated $(0.5$ and $0.3 \mathrm{mg} / \mathrm{mL}$ of each). The bottles were sealed (under continous flushing of $\mathrm{CO} 2$ ) with rubber stoppers and aluminium caps and were placed in a shaking water bath at $39^{\circ} \mathrm{C}$. for 24 hours.

\subsection{Sampling and analysis}

After termination of incubation, the bottles were uncapped and $\mathrm{pH}$ values ware immediately measured using a digital $\mathrm{pH}$ meter. For determination of total VFAs concentrations and individual VFAs proportions $1 \mathrm{~mL}$ of $25 \%$ meta-phosphoric acid was added to $5 \mathrm{~mL}$ of fermentation fluids, centrifuged $(7,000 \times \mathrm{g}$ for $10 \mathrm{~min})$ and

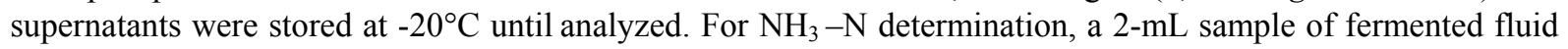
was acidified with $2 \mathrm{~mL}$ of $0.2 \mathrm{~N} \mathrm{HCl}$ and frozen. Samples were centrifuged at $5000 \mathrm{x} g$ for $20 \mathrm{~min}$, and the supernatants were analyzed by spectrophotometry for $\mathrm{NH}_{3}-\mathrm{N}$ according to Chaney and Marbach (1962). Total VFAs concentrations were measured by steam distillation according to Eadie et al. (1967). the percentage concentrations of VFAs were analyzed using High Performance Liquid Chromatography (HPLC; Model Water 600; UV detector, Millipore Crop.) according to the method of Mathew et al. (1997). After the results of the percentage concentrations of VFAs had been received, the following fermentation parameters were calculated:

2.3.1 The amounts of VFA produced were obtained by subtracting the amounts present initially in the incubation medium (blanks) from those determined at the end of the incubation period.

2.3.2 The concentrations of acetic, propionic, butyric and valeric acids in their total concentration.

\subsubsection{Acetic / propionic acid ratio}

2.3.4 Fermentative $\mathrm{CH}_{4}$ production in the buffered rumen fluid were estimated by the equations of Wolin (1960), which has been validated recently by Blummel et al. (1993), as following:

Fermentative $\mathrm{CO}_{2}=\mathrm{A} / 2+\mathrm{P} / 4+1.5 \mathrm{~B}$

Where $\mathrm{A}, \mathrm{P}$ and $\mathrm{B}$ are moles of acetate, propionate, and butyrate respectively.

Fermentative $\mathrm{CH}_{4}=(\mathrm{A}+2 \mathrm{~B})-\mathrm{CO}_{2}$

Where $\mathrm{A}$ and $\mathrm{B}$ are moles of acetate and butyrate respectively and $\mathrm{CO}_{2}$ is moles of $\mathrm{CO}_{2}$ calculated from previous equation.

2.3.5 Percent of methane output per total VFAs production

2.3.6 The fermentation efficiency (FE): This was calculated on the basis of the equation worked out by Orskov (1975) and modified by Baran and Zitnan (2002):

$\mathrm{FE}=(0.622 \mathrm{a}+1.092 \mathrm{p}+1.56 \mathrm{~b}) 100 /(\mathrm{a}+\mathrm{p}+2 \mathrm{~b})$

where: $\mathrm{a}, \mathrm{p}$ and $\mathrm{b}$ express the concentrations ( $\mu \mathrm{mol}$ ) of acetic, propionic and butyric acids respectively in the total concentration of VFAs produced. The final result of this equation is expressed in percentage and shows an amount of energy stored in VFAs as a percentage participation of the initial energy.

2.3.7 The VFAs utilization index: This was expressed by non-glucogenic VFAs/glucogenic VFAs ratio (NGGR) according to Orskov (1975):

$\mathrm{NGGR}=(\mathrm{A}+2 \mathrm{~B}+\mathrm{V}) /(\mathrm{P}+\mathrm{V})$

where $\mathrm{A}, \mathrm{P}, \mathrm{B}$ and $\mathrm{V}$ express the concentrations ( $\mu \mathrm{mol}$ ) of acetic, propionic, butyric and valeric acids respectively. Valeric acid is classified as both glucogenic and non-glucogenic VFA because, its oxidation creates 
1 mole of acetic acid and 1 mole of the propionic acid. Too high NGGR indicates high loss of energy in the form of gases.

\subsection{Measurement of cellulase activity}

Supernatant from each fluid sample was separated by centrifugation at 3,000 $\mathrm{x} g$ for 20 minutes. Half $\mathrm{mL}$ of the supernatant (crude enzyme solution) was mixed with $0.5 \mathrm{~mL}$ of $1 \%$ carboxymethyl cellulose solution in $0.05 \mathrm{M}$ sodium citrate buffer. The reaction proceeded for one hour at $55^{\circ} \mathrm{C}$ without shaking, and then stopped by boiling for $5 \mathrm{~min}$. Boiled samples were centrifuged at $7,000 \times \mathrm{g}$ for $5 \mathrm{~min}$, and reducing sugars produced in the supernatants were measured colorimetrically according to Miller et al. (1960). One unit of enzyme activity was defined as the amount of enzyme that produced $1 \mathrm{mmol}$ of glucose equivalent of reducing sugar per minute.

\subsection{Statistical analysis}

Data were analyzed by one way analysis of variance (ANOVA) test according to Snedecor and Cochran (1980). Treatment means were compared by the least significance difference (LSD) at $5 \%$ level of probability.

\section{Results}

Data presented in table (2) reveals that, fumaric acid-bentontite coupled addition decreased $\mathrm{pH}$ values, $\mathrm{NH}_{3}-\mathrm{N}$ concentrations and butyrate proportions and increased total VFAs concentrations of the fermentation fluid relative to both control and fumaric acid addition. In contrast, addition of fumaric acid alone did not alter any one of the previously mentioned parameters. Furthermore, the overall means of VFAs molar proportions reveals that, both fumaric acid addition and fumaric acid-bentontite coupled addition were associated with increased propionates at the expense of acetates and therefore, a lowered A/P ratio was recorded for both treatments. however, the increment effect induced by coupled addition outdid that induced by fumaric acid addition (33.95\% vs. $12.94 \%$ ). Nevertheless, the molar proportions of the major long chain VFAs (valeric - isovaleric - isobutyric) were not affected by either fumaric acid addition or fumaric acid-bentontite coupled addition. Furthermore, the means of different treatment systems denote that, both fumaric acid addition and fumaric acid-bentontite coupled addition were associated with decreased $\mathrm{CH}_{4}$ production. Neverthless, when $\mathrm{CH}_{4}$ production was calculated as a percent of total VFAs, it appeared that the decremenal effect of coupled addition had exceeded that of fumaric acid addition.

Table (3) identifies that, cellulase activity within the fermentation fluid did not alter by either fumaric acid addition or fumaric acid-bentontite coupled addition relative to control. Nevertheless, the overall means of the calculated fermentation efficiencies reveals that, both fumaric acid addition and fumaric acid-bentontite coupled addition were associated with higher values relative to control, however, the increment effect induced by coupled addition surpassed that induced by fumaric acid addition (3.72\% vs. $1.6 \%)$. In contrast, VFAs utilization index expressed by (NGGR) in both fumaric acid addition and fumaric acid-bentontite coupled addition was lower than control. However, the lowering effect of coupled addition had exceeded that of fumaric acid addition $(34.65 \%$ vs. $15.2 \%)$.

\section{Discussion}

In vitro studies have the advantage not only of being less expensive and less time-consuming, but they also allow maintaining experimental conditions more precisely than do in vivo trials. However, they reflect the pattern but not the extent of rumen fermentation as shown by Demeyer (1991).

Benefits of adding antibiotics to ruminants feed include a shift in the acetate-to-propionate ratio toward more propionate and an associated decrease in methanogenesis (Russell and Houlihan, 2003) that reflects positively on the efficiency of nutrient use by ruminants. Fumarate is an intermediate in one of the pathways of propionate formation (Russell \& Wallace, 1997) and has been extensively studied as an alternative electron sink to ruminal methanogenesis (Castillo et al., 2004). One mol of fumarate converted to propionate would stoichiometrically decrease $\mathrm{CH}_{4}$ production by 5.6 liter (Newbold et al., 2005). however the efficacy of fumarate to play this role is limited by the inability of fumarate-reducers to compete for $\mathrm{H}_{2}$ with methanogens. this study is an attempt to potentiate the efficacy of fumarate reduction into propionates and improving fermentation efficiency by coupling bentonite to fumaric acid addition.

From the foregoing results it has been observed that, coupling bentonite to fumaric acid addition was associated with an additional increase in propionic acid production that was accompanied by additional decrease in $\mathrm{CH}_{4}$ production relative to addition of fumaric acid singly. The influence of bentonite on rumen fermentation pattern was examined in several studies. Galyean and Chabot (1981) did not find any significant changes in the VFAs profile of bull rumen under the influence of a mineral mixture containing sodium bentonite. The rumen parameters were examined in sheep supplemented with bentonite, and no significant differences were found in 
case of animals fed bulky feed, whereas when they were fed concentrate, an increase in the percentage participation of acetate at the expence of propionate was obtained (Murray et al., 1990), thus the effect was opposite to the one obtained in this research. Moreover, addition of magnesium-mica to heifers did not cause any significant changes in ruminal VFAs content (Coffey et al., 2000). Therefore, increased propionates under the influence of fumaric acid-bentontite coupled addition seems to be first of all, a result of fumaric acid itself. However, the additional increase in propionic acid production achieved by coupling bentonite to fumaric acid could be really attributed to the antagonistic actions that bentonite exerts on protozoal - methangens and protozoal - amylolytic bacteria interrelationships. Bentonite interferes with protozoal activity (Wallace \& Newbold, 1991) and some ruminal methanogens associate metabolically with protozoa for greater $\mathrm{H}_{2}$ availability (Finlay et al., 1994) a relation that may augments the capacity of methanogens to compete for $\mathrm{H}_{2}$ with fumaratereducers. In agreement, fumarate effects on methanogenesis were more pronounced in protozoa-depleted than in protozoa-enriched ruminal fluid (Asanuma et al., 1999). In this regard coupling bentonite to fumaric acid could give fumarate-reducers an advantage in the competition for $\mathrm{H}_{2}$ with methanogens. Additinally, protozoa ingest both starch grains and amylolytic bacteria associated with them (Jouany, 1997). These amylolytic bacteria are succinate producing and act synergistically with succinate decarboxylating Selenomonas ruminantium to give propionates leading to better energy use since propionate metabolism is more favorable than acetate and butyrate ones (Eugene et al., 2004). In this regard and because of its small particle size, protozoa are probably deceived into gathering bentonite particles instead of starch and bacterial particles. Bentonite slows the capture rate of microbes by protozoa because of its huge surface area and the electrical charges on its surface (Heijnen et al., 1991, Wallace \& Newbold, 1991). This also could provide more substrates for amylolytic bacterial attack and probably this might be the cause of higher VFAs concentrations achieved by coupled addition. Moreover, the observed decrease in butyrates molar proportions associated with coupled addition is probably also related to decreased protozoal activities since it is well established that protozoa are important butyrate producers (Jouany, 1991).

In this research, neither fumaric acid addition nor fumaric acid-bentontite coupled addition altered the profile of the major long chain VFAs (valeric - isovaleric - isobutyric). This probably reveals a balanced microbial deaminative activity as deamination of branched chain amino acids represents the major source of long chain VFAs (Hino \& Russell, 1985).

The tendency to lower $\mathrm{NH}_{3}-\mathrm{N}$ concentrations in the fermentation fluid observed by coupled addition could be attributed either to a greater ammonia utilization by rumen microbes or to the great ability of bentonite to adsorb ammonia when present at high concentrations (Saleh, 1994). Furthermore, inhibition of protozoa is often associated with reduced ruminal $\mathrm{NH}_{3}-\mathrm{N}$ concentration (Williams \& Withers, 1993) presumably resulting from a reduction in protozoal proteolytic and deaminative activity.

The recorded $\mathrm{pH}$ values here were within the normal range required for optimum microbial activities (Russell and Wilson, 1996). One could expect that the concentrations of VFAs and $\mathrm{NH}_{3}$ in the fermentation fluid have a decisive influence on the recorded $\mathrm{pH}$, as they are the main sources of $\mathrm{H}^{+}$and $\mathrm{OH}^{-}$and hence, reduction of $\mathrm{pH}$ associated with coupled addition is corresponded well with VFAs and $\mathrm{NH}_{3}$ concentrations.

Advantageously, cellulase activity within the fermentation fluid did not alter by coupled addition which points to efficient $\mathrm{H}_{2}$ disposal without negative drawbacks on cellulolytic bacterial actvity. Conversely, bentonite can improve fungal cellulolytic activity by protecting fungal rhizobium against predation by rumen protozoa as suggested by Heijnen et al. (1991).

The fermentation efficiencies calculated in this study were in the following order: fumaric acid-bentontite coupled addition $>$ fumaric acid addition $>$ control. The value for coupled addition amounted to $80.82 \%$ and this was higher than the value calculated for fumaric acid addition by about $1.6 \%$ and higher than that calculated for control by about $2.9 \%$. Calculation of fermentation efficiency is based on conversion of hexose energy to VFAs energy on the basis of equations worked out by Orskov (1975) and modified by Baran and Zitnan (2002). Metabolism of VFAs is less efficient than metabolism of glucose as more energy is used for formation of one mole of ATP (Livesey and Elia, 1995). It is clear that increased fermentation efficiency acheived by coupled addition is actually the end result of its decremental effect on methane production and its ability to increase propionates a the expence of acetates and butyrates. In contrast to fermentation efficiency, VFAs utilization index (NGGR) being optimum at values amounts to 3.5 and higher values indicate the worse use of VFA (Czerkawski, 1986). The lowest value of NGGR, which indicates the best utilization of VFA, was achieved by fumaric acid-bentontite coupled addition (2.15). The 34.6\% improvement in VFAs utilization under the influence of coupled addition versus $15.2 \%$ for addition of fumaric acid singly indicates an increase in the contribution of glucogenic VFAs in their total amount. 


\section{Conclusion}

The principal effects of coupling bentonite to fumaric acid addition on in vitro rumen fermentation include increased contribution of propionate in the total VFAs concentrations, decreased methane production, improved fermentation efficiency and the rise of glucogenic VFA content compared to non-glucogenic ones. These results suggest that coupling bentonite to fumaric acid addition could be a feasible strategy for intensifying the response of rumen microbial system for addition of fumaric acid to smooth the progress of its use as a feed additive instead of ionofores. Even so, additional in vivo studies are needed to settle on the probable adaptation of rumen microflora to this coupled addition and its effect on animal performance.

\section{References}

Asanuma, A., Iwamoto, M., \& Hino, T. (1999). Effect of the addition of fumarate on methane production by ruminal microorganisms in vitro. Journal of Dairy Science, 82, 780-787.

Baran, M., \& Zitnan, R. (2002). Effect of monensin sodium on fermentation efficiency in sheep rumen. Arch. Tierzucht, 45, 181-185.

Bates, R. L., \& Jackson, J. A. (1980). Glossary of Geology. American Geological Institute, Alexandria, VA 22302.

Blummel, M., Steingass, H., Becker, K., \& Soller, H. (1993). Production of SCFA, CO2, CH4 and microbial cells in vitro. Proceedings of the Society of Nutrition Physiology. 1: 9.

Castillo, C., Benedito, J. L., Mendez, J., Pereira, V., Lopez-Alonso, M., Miranda, M., \& Hernandez, J. (2004). Organic acids as a substitute for monensin in diets for beef cattle. Animal Feed Science and Technology, 115, 101-116.

Chaney, A. L., \& Marbach, E. P. (1962). Modified reagents for determination of urea and ammonia. Clinical Chemistry, 8,130-132

Coffey, K. P., Nagaraja, T. G., Towne, E. G., Brazle, F. K., \& Moyer, J. L. (2000). Digestibility of prairie diets supplemented with different levels of magnesium-mica by beef heifers. Journal of Animal Science, 78, 718-725.

Czerkawski, J. W. (1986). An introduction to rumen studies. Pergamon Press, Oxford.

Demeyer, D. I. (1991). Quantitative aspects of microbial metabolism in the rumen and hindgut. In J. B. B. Jouany (ed), Rumen Microbial Metabolism and Ruminal Digestion (pp. 217-237). Paris : INRA Editions.

Diebold, G., \& Eidelsburger, U. (2006). Acidification of diets as an alternative to antibiotic growth promoters. In Barug. D., de Jong, J., Kies, A. K., \& M. W. A., Verstegen (eds), Antimicrobial Growth Promoters. (pp. 311327). The Netherlands :Wageningen Academic Publishers.

Eadie, J. M., Hobson, P. N., \& Mann, S. O. (1967). A note on some comparisons between the rumen content of barley fed steers and that of young calves also fed on high concentrate rations. Animal production, 9, $247-251$.

Eugene, M., Archimede, H., Michalet, B., \& fonty, G. (2004). Effects of defaunation on microbial activities in the rumen of rams consuming a mixed diet (fresh Digitaria decumbens grass and concentrate). Animal Research, 53,187-200.

Fenn, P. D., \& Leng, R. A. (1989). Wool growth and sulfur amino acid entry rate in sheep fed roughage based diets supplemented with bentonite and sulfur amino acids. Australian Journal of Agriculutre Research, 40, 889896.

Finlay, B. J., Esteban, G., Clarke, K. J., Williams, A. G., Embley, T. M., \& Hirt, R. P. (1994). Some rumen ciliates have endosymbiotic methanogens. FEMS Microbiology Letter, 117, 157-161.

Galyean, M. L., \& Chabot, R. C. (1981). Effects of sodium bentonite, buffer salts, cement kiln dust and clinoptiolite on rumen characteristics of beef steers fed a high roughage diet. Journal of Animal Science, 52, 1197-1204.

Goering, H. K., \& Van Soest, P. J. (1970). Forage Fiber Analysis. Agricultural Handbook no. 379. Washington, DC: Agricultural Research Service, US Department of Agriculture.

Heijnen, C. E., Hok-A-Hin, C. H., \& VanVeen, J. A. (1991). Protection of rhizobium by bentonite clay against predation by flagellates in liquid cultures. FEMS Microbiology Ecology, 85, 65-72.

Hino, T., \& Russell, J. B. (1985). Effect of reducing - equivalent disposal and NADH/NAD on deamination of amino acids by intact rumen microorganisms and their cell extract. Applied Environmental Microbiology, 50, 1368-1374. 
Jouany J.P. (1991). Defaunation of the rumen, in: Jouany J.P. (Ed.), Rumen microbial metabolism and ruminant digestion, (pp. 239-261). Paris: INRA Editions.

Jouany J.P. (1997). Effect of protozoa in plant cell wall and starch digestion in the rumen, In Onodera R. et al. (Eds.), Rumen microbes and digestive physiology in ruminants, (pp. 11-24). Tokyo/S. Karger, Basel: Japan Sci. Soc. Press.

Livesey, G., \& Elia, M. (1995). Short-chain fatty acids as an energy source in the colon: metabolism and clinical implications. In Cummings, J. H., Rombeau, J. L., \& Sakata, T. (Eds.), Physiological and clinical aspects of short-chain fatty acids, (pp. 427-481). London: Cambridge University Press.

Mathew, S., Sagathevan, S., Thomas, J., \& Mathen, G. (1997). An HPLC method for estimation of volatile fatty acids in ruminal fluid. Indian Journal of Animal Sciences, 67, 805- 807.

Miller, J. L., Blum, R., Glennon, W. E., \& Burton, A. L. (1960). Measurement of carboxymethyl cellulase activity. Analytical Biochemistry, 1, 127-132.

Murray, P. J., Rowe, J. B., \& Aitchison, E. M. (1990). The effect of bentonite on wool growth, liveweight change and rumen fermentation in sheep. Australian Journal of Experimenal Agriculture, 30, 39-42.

Newbold, C. J., \& Rode, L. M. (2006). Dietary additives to control methanogenesis in the rumen. International Congress Series 1293, 138-147.

Newbold, C. J., Lopez, S., Nelson, N., Ouda, J. O., Wallace, R. J., \& Moss, A. R. (2005). Propionate precursors and other metabolic intermediates as possible alternative electron acceptors to methanogenesis in ruminal fermentation in vitro. British Journal of Nutrition, 94, 27-35.

Newbold, C. J., Lassalas, B., \& Jouany, J. P. (1995). The importance of methanogens associated with ciliate protozoa in ruminal methane production in vitro. Letters in Applied Microbiology, 21, 230-234

Orskov, E. R. (1975). Manipulation of rumen fermentation for maximum food utilization. World Reveiw Nutrition Diet, 22, 153-182.

Russell, J. B., \& Houlihan, A. J. (2003). The ionophore resistance ruminal bacteria and its potential impact on human health. FEMS Microbiology Review, 27,65-74.

Russell, J. B., \& Wallace, R. J. (1997). Energy-yielding and energy-consuming reactions. In Hobson, P. N., \& Stewart, C. S.(Eds.), The Rumen Microbial Ecosystem (PP. 246). London, UK: Blackie Academic and Professional.

Russell, J. B., \& Welson, R. J. (1996). Why are ruminal cellulolytic bacteria unable to digest cellulose at low $\mathrm{pH}$ ? Journal of Dairy Science, 79, 1503-1509.

Saleh, M. S. (1994). Using of feed additives for feeding farm animals. Ph.D. Thesis, Fac. of Agric. Kafr ElSheikh, Tanta University, Egypt.

Santra, A., Kamra, D. N., \& Pathak, N. N. (1996). Influence of ciliate protozoa on biochemical changes and hydrolytic enzymes in the rumen of Murrah buffalo (Bubalus Bubalis). Buffalo Journal 1, 95-100.

Snedecor, G. W., \& Cochran, W. G. (1980). Statistical methods. Oxford an J.B.H.puplishing com. 7th edition.

Wallace, R. J., \& Newbold, C. J. (1991). Effect of bentonite on fermentation in the rumen simulation technique (Rusitec) and rumen ciliate protozoa. Journal of Agriculture Science Cambridge, 116, 163-168.

Wallace, R.J., Wood, T.A., Rowe, A., Price, J., Yanez, D.R., Williams S.P., \& Newbold C.J. (2005). Encapsulated fumaric acid as a means of decreasing ruminal methane emissions, International Congress Series, 1293, 148-151.

Williams, A. G., \& Withers, S. E. (1993). Changes in the rumen microbial populations and its activities during the refaunation period after the reintroduction of ciliate protozoa into the rumen of defaunated sheep. Canadian Journal of Microbiology, 31, 61-69.

Wolin, M. J. (1960). A Theoretical rumen fermentation balance. Journal of Dairy Science, 43, 1452-1459. 
Table 1. Composition and chemical analysis of the used basal diet

\begin{tabular}{|l|l|l|l|}
\hline Ingredients & $\%$ as fed & Chemical analysis & $\%$ of dry matter \\
\hline Barely grain & 39.56 & Crude fibers & 31.00 \\
\hline Berseem hay & 40.00 & Crude proteins & 13.00 \\
\hline Wheat straw & 20.14 & Ether extract & 2.80 \\
\hline Vitamin and mineral premix & 0.30 & Nitrogen free extract & 32.50 \\
\hline & & total ash & 10.60 \\
\hline & & Digestible energy (kcal $/ \mathrm{kg} \mathrm{diet})$ & 2200 \\
\hline
\end{tabular}

Table 2. Effect of treatment systems on fermentation pattern by mixed rumen micro-organisms after 24 hours in vitro incubation

\begin{tabular}{|c|c|c|c|c|}
\hline Parameter & $\begin{array}{l}\text { Control (no } \\
\text { additives) }\end{array}$ & Fumaric acid addition & $\begin{array}{l}\text { Fumaric } \\
\text { acid-bentonite } \\
\text { coupled addition }\end{array}$ & L.S.D. \\
\hline $\mathrm{P}^{\mathrm{H}}$ value & $6.58^{\mathrm{a}} \pm 0.49$ & $6.52^{\mathrm{a}} \pm 0.05$ & $6.19^{b} \pm 0.11$ & 0.148 \\
\hline Total VFAs conc. $(\mu \mathrm{mol})$ & $898.2^{\mathrm{a}} \pm 22.84$ & $916.2^{\mathrm{a}} \pm 24.82$ & $1091.4^{b} \pm 16.36$ & 66.698 \\
\hline Acetic acid (mol/100 mol) & $49.89^{\mathrm{a}} \pm 0.25$ & $46.99^{b} \pm 0.56$ & $44.95^{c} \pm 0.21$ & 1.16 \\
\hline Propionic acid (mol/100 mol) & $24.80^{\mathrm{a}} \pm 0.34$ & $28.01^{b^{b}} \pm 0.53$ & $33.22^{c} \pm 0.34$ & 1.277 \\
\hline Butyric acid (mol/100 mol) & $19.04^{\mathrm{a}} \pm 0.43$ & $18.49^{\mathrm{a}} \pm 0.29$ & $15.00^{b} \pm 0.32$ & 1.093 \\
\hline Acetic / propionic ratio & $2.01^{\mathrm{a}} \pm 0.03$ & $1.67^{\mathrm{b}} \pm 0.05$ & $1.35^{\mathrm{c}} \pm 0.02$ & 0.108 \\
\hline Valeric $(\mathrm{mol} / 100 \mathrm{~mol})$ & $3.20 \pm 0.198$ & $3.02 \pm 0.199$ & $2.86 \pm 0.150$ & NS \\
\hline Isovaleric $(\mathrm{mol} / 100 \mathrm{~mol})$ & $1.08 \pm 0.09$ & $1.30 \pm 0.19$ & $1.25 \pm 0.20$ & NS \\
\hline Isobutyric (mol/100 mol) & $1.97 \pm 0.28$ & $2.17 \pm 0.28$ & $2.28 \pm 0.20$ & NS \\
\hline $\mathrm{CH}_{4}(\mu \mathrm{mol})$ & $253.42^{\mathrm{a}} \pm 6.61$ & $234.78^{b} \pm 6.55$ & $236.49^{b} \pm 5.52$ & 12.264 \\
\hline $\mathrm{CH}_{4} /$ total VFAs $(\%)$ & $28.26^{\mathrm{a}} \pm 0.12$ & $25.63 \mathrm{~b}_{ \pm 0.44}$ & $21.66^{c} \pm 0.23$ & 1.012 \\
\hline Ammonia N. conc. $(\mathrm{mg} / \mathrm{dl})$ & $11.62^{\mathrm{a}} \pm 0.49$ & $11.55^{\mathrm{a}} \pm 0.54$ & $7.69^{b} \pm 0.51$ & 1.594 \\
\hline
\end{tabular}

Data presented as means $\pm S E, N=5$

Values having different letters in the same raw are significantly different at $P<0.05$

Table 3. Effect of treatment systems on cellulase activity, fementation efficiency and VFAs utilization index (NGGR) after 24 hours in vitro incubation

\begin{tabular}{|c|c|c|c|c|}
\hline parameter & $\begin{array}{l}\text { Control (no } \\
\text { additives) }\end{array}$ & $\begin{array}{l}\text { Fumaric acid } \\
\text { addition }\end{array}$ & $\begin{array}{l}\text { Fumaric acid-bentonite } \\
\text { coupled addition }\end{array}$ & L.S.D. \\
\hline $\begin{array}{l}\text { Cellulase activity (mmol of glucose } \\
\text { equivalent } / \mathrm{min})\end{array}$ & $5.29 \pm 0.119$ & $5.18 \pm 0.149$ & $5.46 \pm 0.113$ & NS \\
\hline Fementation efficiency (\%) & $77.92^{\mathrm{a}} \pm 0.072$ & $79.17^{b} \pm 0.228$ & $80.82^{c} \pm 0.307$ & 0.692 \\
\hline VFAs utilization index (NGGR) & $3.30^{\mathrm{a}} \pm 0.08$ & $2.79^{b} \pm 0.06$ & $2.15^{\mathrm{c}} \pm 0.04$ & 0.198 \\
\hline
\end{tabular}

Data presented as means $\pm S E, N=5$

Values having different letters in the same raw are significantly different at $P<0.05$ 